\title{
PENGARUH ARUS KAS TERHADAP LIKUIDITAS PERUSAHAAN PADA PERUSAHAAN MANUFAKTUR YANG GO PUBLIC SUB SEKTOR INDUSTRIBARANG KONSUMSI
}

\author{
Ni Putu Astri Purnama Dewi \\ Luh Kade Datrini \\ L.G.P Sri Eka Jayanti \\ Fakultas Ekonomi dan Bisnis Universitas Warmadewa
}

\begin{abstract}
ABSTRAK
Penelitian ini dilakukan dengan tujuan untuk menguji secara empiris ada atau tidaknya pengaruh arus kas dari aktivitas operasi, arus kas dari aktivitas investasi dan arus kas dar I aktivitas pendanaan terhadap likuiditas perusahaan pada sub sektor industri barang konsumsi yang terdaftar di BEI (Bursa Efek Indonesia). Populasi pada penelitian ini berjumlah 42 perusahaan sub sektor industri barang konsumsi yang terdaftar di Bursa Efek Indonesia.

Metode pengumpulan data yang digunakan adalah dengan dokumentasi. Teknik analisis data menggunakan analisis regresi linear berganda. Dan teknik pengambilan sampel adalah dengan purposive sampling dengan hasil yang didapat adalah 35 perusahaan yang memenuhi syarat. Hasil pada penelitian ini adalah bahwa secara parsial arus kas dari aktivitas operasi tidak memiliki pengaruh terhadap likuiditas perusahaan sedangkan arus kas dari aktivitas investasi dan arus kas dari aktivitas pendanaan memiliki pengaruh terhadap likuiditas perusahaan. Secara simultan arus kas operasi, arus kas investasi dan arus kas pendanaan memiliki pengaruh terhadap likuiditas perusahaan.
\end{abstract}

Kata Kunci: Arus Kas Operasi, Arus Kas Investasi, Arus Kas Pendanaan, Likuiditas Perusahaan

\section{PENDAHULUAN}

\section{A. Latar Belakang Masalah}

Dalam era globalisasi dunia saat ini banyak usaha yang semakin maju dan berkembang, contohnya dalam bidang keuangan, bidang keuangan memiliki peran penting bagi perusahaan, hasil dari bidang keuangan ini adalah laporan keuangan. Laporan ini menyajikan informasi lengkap hasil dari kegiatan perusahaan selama satu periode. Dalam laporan arus kas menyajikan jumlah uang yang dihasilkan dari beberapa aktivitas, seperti aktivitas operasi, investasi dan pendanan. Kas yang dihasilkan dari masing masing aktivitas sangat penting diketahui perusahaan, hal ini karena laporan arus kas akan dinilai seberapa besar masing-masing aktivitas tersebut menyumbang kas dalam perusahaan. Banyak kasus dimana perusahan yang tergolong bonafit namun tidak dapat membayar kewajiban jangka pendeknya yang segera jatuh tempo. Laba yang dihasilkan tidak mencerminkan kas yang tersedia dalam perusahaan, karena perusahaan menggunkan prinsip acural basis (munawir, 2014). Kesulitan dalam membayar kewajiban yang segera jatuh tempo karena perusahaan tidak memiliki cukup dana atau rendahnya ketersedian kas pada perusahaan. Untuk mengukur kemampuan perusahaan dalam membayar hutang lancarnya yang akan jatuh tempo, diperlukan suatu rasio. Rasio yang digunakan untuk menyelesaikan adalah rasio likuiditas. Rasio ini menilai 
seberapa kemampuan aset lancar yang di miliki perusahaan untuk membayar hutang lancarnya yang akan jatuh tempo.

Penelitian tentang pengaruh dari arus kas operasi, arus kas investasi dan arus kas pendanaan terhadap likuiditas perusahaan telah beberapa kali dilakukan. Penelitian (Ina Hertina, 2012) menyimpulkan arus kas operasi, arus kas investasi dan arus kas pendanaan berpengaruh terhadap likuiditas perusahaan. Penelitian menurut (Sutisna S, 2008) menyimpulkan bahwa arus kas operasi, arus kas invetasi dan arus kas pendanaan berpengaruh terhadap likuiditas pada perusahaan.

Penelitian menurut (Nurul H, 2010). Menyimpulkan bahwa arus kas pendanaan memiliki pengaruh terhadap likuiditas pada perusahaan sedangkan arus kas operasi dan arus kas invetasi tidak berpengaruh terhadap likuiditas pada likuiditas perusahaan. Penelitian menurut (Hanum Masayu,2017) menyimpulkan arus kas investasi berpengaruh terhadap likuiditas pada likuiditas perusahaan sedangkan arus kas operasi dan arus kas pendanaan tidak berpengaruh terhadap likuiditas pada perusahaan. Penelitian menurut (Ayuni R, 2017) menyimpulkan arus kas operasi tidak berpengaruh terhadap likuiditas perusahaan. Sedangkan penelitian menurut (Melisa P, 2017) menyimpulkan arus kas operasi memiliki pengaruh signifikan terhadap likuiditas perusahaan.

Berdasarkan pemaparan kasus ini, maka tujuan dari penelitian ini adalah menguji secara empiris pengaruh arus kas operasi, arus kas investasi dan arus kas pendanaan terhadap likuiditas perusahaan.

\section{TINJAUAN PUSTAKA}

\section{A. Landasan Teori}

Menurut (Harahap, 2017) kas adalah aset perusahaan yang paling lancar, digunakan untuk membiayai kegiatan operasional perusahaan. Karena sifatnya yang sangat likuid, maka di perlukan suatu laporan yang merinci penggunaan kas. Arus Kas menurut I Made Sudana (2011) adalah alur dari penerimaan dan pengerluan transaksi yang hanya melibatkan kas dalam suatu perusahaan. Menurut (Bambang R, 2011) mengemukaan bahwa laporan arus kas adalah laporan laporan yang menunjukkan perincian dari arus kas masuk (penerimaan) dan keluar (pengeluar an) suatu perusahaan pada suatu periode tertentu. Laporan arus kas dibuat setelah pembuatan neraca keuangan dan disusun berdasarkan data laporan laba rugi periode berjalan serta data dari neraca periode sebelumnya. Laporan arus kas, baik untuk perusahaan barang ataupun jasa, mempunyai klasifikasi yang dibagi menjadi 3 jenis aktivitas, yaitu operasional, investasi dan pendanaan. Likuiditas menurut (Emili S, 2017) adalah kemampuan asset lancer yang dimiliki oleh perusahaan untuk membayar kewajiban jangka pendek yang segera jatuh tempo. Hubungan arus kas dan likuiditas adalah nilai yang dihasilkan dari arus kas dapat membantu penggunanya untuk mengevaluasi suatu likuiditas. Bahwa dengan melihat laporan arus kas dapat mengetahui apakah kondisi likuiditas perusahaan kuat atau ilikuid. Untuk menguji laporan keuangan yang dibuat perusahaan, untuk mengukur likuiditas perusahaan, maka di perlukan suatu rasio. Rasio yang tepat untuk menghitung tingkat likuiditas adalah rasio likuiditas. Rasio lancer menggunakan rumus asset lancar dibagi dengan kewajiban lancar. Rasio sangat lancar menggunkan rumus aset lancar dikurangi jumlah persediaan dibagi dengan kewajiban lancar, dan rasio kas menggunkan rumus jumlah kas dan setara kas dibagi dengan kewajiban lancar.

\section{B. Hipotesis}

Menurut (Nata wirawan, 2016) Hipotesis adalah dugaan sementara dari sebuah pertanyaan. Hipotesis ini dibuat dengan membandingan teori yang ada dan hasil dari 
peneliti sebelumnya, sehingga pada penelitian ini, didapat hipotesis yaitu :

Ha1 : Terdapat pengaruh yang signifikan Arus Kas Operasi Terhadap Likuiditas Perusahaan Manufaktur go public Sektor Industri Barang Konsumsi di BEI periode Tahun 2013-2017.

$\mathrm{Ha} 2$ : Terdapat pengaruh yang signifikan antara Arus Kas Investasi Terhadap Likuiditas Perusahaan Manufaktur go public Sektor Industri Barang Konsumsi di BEI periode Tahun 2013-2017.

Ha3 : Terdapat pengaruh yang signifikan antara Arus Kas Pendanaan Terhadap Likuiditas Perusahaan Manufaktur go public Sektor Industri Barang Konsumsi di BEI periode Tahun 2013-2017.

Ha4 : Terdapat pengaruh yang signifikan Arus Kas Operasi, Arus Kas Invetasi dan Arus Kas Pendanaan Terhadap Likuiditas Perusahaan Manufaktur go public Sektor Industri Barang Konsumsi di BEI periode Tahun 2013-2017.

\section{METODE PENELITIAN}

Metode penelitian ini menggunakan teknik pengumpulan data dengan dokumentasi mengakses website BEI (Bursa Efek Indonesia) di www.idx.co.id. Penelitian dilakukan pada perusahaan sector industry barang konsumsi selama periode 2013 hingga 2017. Pada penelitian ini sampel diambil menggunakan teknik purposive sampling. Sampel yang digunakan sebanyak 35 perusahan dikalikan 5 tahun periode penelitian 2013-2017 jadi total sampel yang diteliti sebanyak 175 sampel. Penelitian ini menggunakan teknik analisis yaitu teknik analisis regresi linier berganda.

\section{HASIL DAN PEMBAHASAN}

A. Analisis Regresi Berganda
Hasil analisis regresi berganda diperoleh persamaan sebagai berikut:

$\mathrm{Y}=1,584+1,307 \mathrm{E}-13 \mathrm{X} 1+2,072 \mathrm{E}-13 \mathrm{X} 2$

$+1,817 \mathrm{E}-13 \mathrm{X} 3$

B. Uji Goodness of fit

Uji Goodness of fit terdiri dari:

1. Analisis Determinasi

Hasil uji determinasi didapatkan besarnya nilai Adjusted $R$ Square adalah sebesar 0.053 , Artinya variasi (naik turunnya) likuiditas (Y), mampu di terangkan oleh perubahan Arus kas dari aktivitas operasi (X1), arus kas dari aktivitas investasi(X2), dan arus kas dari aktivitas pendanaan1(X3), secara bersamaan mempengaruhi sebesar 5,30\%, sementara itu sebesar $94,70 \%$, nilai ini dipengaruhi dari variable lain yang tidak diteliti dalam penelitianlini.

2. Uji Kelayakan Model (Uji F)

Dari hasil uji kelayakan model diperoleh hasil besarnya sig $\mathrm{F}$ senilai 0,030. Hasil tersebut lebih1kecil1dari1standar sig 0.05 . Sehingga dapat dikatakan model regresi pada penelitian ini layak digunakan.

3. Uji t

Hasil ujit dapat dilihat berdasarkan tabel hasil penelitian dibawah ini:

Hasil analisis regresi berganda

\begin{tabular}{|ll|l|l|}
\hline Model & & & Sig. \\
& & & \\
\hline 1 & (Constant) & 20,268 & 0,000 \\
& AKO & 1,827 & 0,070 \\
& AKI & 2,508 & 0,013 \\
& AKP & 2,505 & 0,013 \\
\hline
\end{tabular}

Sumber: data diolah

Dapat dilihat bahwa nilai signifikansi uji t dari: 
1) Variabel (X1) yaitu Arus Kas Operasi mempunyai nilai sig sebesar 0,070. Nilai pada hasil penelitian ini lebih besar dari standar sig yaitu 0,050 . Dari hasil analisis ini menunjukkan secara1parsial varibel Arus Kas Operasi $\left(\mathrm{X}^{1}\right)$ ini tidak berpengaruh terhadap likuiditas.

2) Variabel Arus Kas Investasi $\left(X^{2}\right)$ mempunyai nilai signifikansi sebesar 0,013. Nilai ini lebih kecil dari standar sig yaitu 0,050 . Dari hasil analisis ini menunjukkan secara parsial Arus Kas Investasi mempunyai pengaruh terhadap likuiditas.

3) Variabel Arus Kas Pendanaan $\left(X^{3}\right)$ mempunyai nilai signifikansi sebesar 0,013. Nilai Ini lebih kecil dari standar sig yaitu 0,05. Dari hasil analisis menunjukkan secara parsial Arus Kas Pendanaan mempunyai pengaruh terhadap likuiditas.

\section{SIMPULAN DAN SARAN}

\section{A. Simpulan}

1. Variabel Arus Kas dari aktivitas operasi tidak berpengaruh terhadap liku iditas perusahaan. Hasil ini dikarenakan peningkatan dan penurunan dari arus kas aktivitas operasi tidak mempengaruhi likuiditas. Hal lain yang mendukung hasil analisis ini adalah kas yang dihasilkan pada aktivitas ini tidak dapat mempengaruhi rasio likuiditas yang dihasilkan, dikarenakan kas yang dihasilkan pada aktivitas ini hanya membiayai keperluan dari aktivitas operasi saja, sedangkan untuk pembayaran hutang jangka pendek memerlukan pendanaan dari luar.
2. Variabel Arus Kas dari aktivitas Investasi berpengaruh terhadap likuiditas perusahaan. Hasil ini dikarenakan peningkatan dan penuruan dari arus kas aktivitas investasi mempengaruhi likuiditas. Hubungan antara arus kas investasi dengan likuiditas didasarkan pada asumsi bahwa jumlah arus kas dari aktivitas investasi akan mempengaruhi jumlah kas dan setara kas yang digunakan untuk perolehan dan pelepasan aktiva tetap, sehingga akan mempengaruhi tingkat likuiditas

3. Arus Kas dari aktivitas pendanaan Pendanaan berpengaruh terhadap likuiditas perusahaan. Hasil ini dikarenakan peningkatan dan penuruan dari arus kas aktivitas pendanaan mempengaruhi likuiditas. Kondisi ini dapat dijelaskan bahwa jumlah arus kas dari aktivitas pendanaan akan mempengaruhi jumlah kas dan setara kas yang digunakan untuk menambah atau mengurangi jumlah dan komposisi modal serta hutang jangka panjangnya.

4. Secara Simultan, variabel Arus kas operasi, arus kas investasi, arus kas pendanaan secara bersama sama berpengaruh terhadap likuiditas perusahaan.

\section{B. Saran}

1. Bagi Perusahaan

a. komponen penting yaitu arus kas operasi, arus kas investasi, dan arus kas pendanaan perlu mendapatkan perhatian dari pihak perusahaan.

b. Kegiatan investasi dan kegiatan pendanaan perlu ditingkatkan lagi karena arus kas ini secara parsial memberikan pengaruh yang signifikan terhadap likuiditas perusaahan. Arus kas investasi 
meskipun memiliki pengaruh terhadap likuiditas namun perlu diupayakan agar kas yang keluar dapat se-efektif mungkin agar tidak menjadi pemborosan dan kekosongan kas dalam perusahaan,

2. Bagi Peneliti Selanjutnya

a. Peneliti selanjutnya diharapkan dapat menggunakan rasio keuangan lainnya untuk menguji hasil penelitian yang lebih baik. Yang berguna bagi pemakai informasi laporan keuangan.

b. Peneliti selanjutnya diharapkan menggunakan periode penelitian yang berbeda dengan jarak waktu lebih lama untuk menunjang hasil penelitian yang lebih baik.

\section{DAFTAR1PUSTAKA}

Hery, 2017. Teori Akuntansi pendekatan konsep dan analisi. Jakarta: Grasindo

Arikunto, S. 2010. Prosedur Penelitian Suatu Pendekata Praktik. Jakarta: Rineka Cipta.

Harahap, Sofyan Syafri. 2017. “Analisis Kritis Atas Laporan Keuangan”. Jakarta: Raja Grafindo Persada.

Munawir.12015. Analisis Laporan Keuangan. Yogyakarta : Edisi Empat, Liberty.

Kasmir, (2016). Analisis Laporan Keuangan, Penerbit Raja Grafindo Persada, Jakarta.

Munawir, (2014) Analisa Laporan Keuangan, Edisi Keempat, Penerbit Liberty, Yogyakarta.

Nata Wirawan, (2001), Statistik 1 (Statistik Deskriptif) Untuk Ekonomi dan Bisnis,
Edisi Kedua, Penerbit Keraras Emas, Denpasar.

Ina Hertina, (2012), Pengaruh Arus Kas Terhadap Likuiditas Studi Kasus Pada PD. Sumber Makmur Tasikmalaya. Jurnal Akuntansi, Universitas Siliwangi, Tasikmalaya.

Melisa Paulin Rais (2017), Pengaruh Arus Kas Operasi Terhadap Likuiditas Perusahaan Sub Sektot Telekomunikasi Yang Terdaftar Di Bursa Efek Indonesi. Jurnal Akuntansi, Universitas Pakuan, Bogor.

Ayuni Rizki Wulandari (2017), Pengaruh Arus Kas Aktivitas Operasi Terhadap Tingkat Likuiditas. Jurnal Akuntansi, Universitas Bina Insani, Bekasi.

Nurul Hayati dan Christina Riani (2011), Pengaruh Arus Kas Terhadap Likuiditas Pada Perusahaan Telekomunikasi Yang Terdaftar Di BEI. Jurnal Akuntansi, Sekolah Tinggi Ilmu Ekonomi Indonesia, Banjarmasin.

Nurmiati (2016), Pengaruh Arus Kas Operasi Terhadap Likuiditas Perusahaan Farmasi Yang Terdaftar di Bursa Efek Indonesia, Jurnal Akuntansi, Universitas Negeri, Makasar.

Hanum Masayu Kirnasari (2012), Pengaruh Arus Kas Terhadap Likuiditas Industri Barang Konsumsi Yang Terdaftar Di Bursa Efek Indonesia Periode 2009 - 2011, Jurnal Akuntansi, Universitas Negeri Surabaya, Surabaya.

www.idx.co.id. Laporan Keuangan Sektor Industri Barang Konsumsi Tahun 2013 - 2017 